\title{
Evaluasi Psikometris General Health Questionnaire (GHQ) 28 Pada Subjek Mahasiswa di Semarang, Jawa Tengah
}

\author{
Diany Ufieta Syafitri ${ }^{1}$ \\ 1Fakultas Psikologi Universitas Islam Sultan Agung \\ dianysyafitri@unissula.ac.id
}

\begin{abstract}
: the age range of adolescents through young adults are considered susceptive to various mental health problems. It is also reported in news and research reports that college students which are falls in that age rage category, have high probability of experiencing mental health problems. One of the most important obstacles in mental health system in Indonesia is the lack of mental health screening tool. There already some screening tools existed but there is not adequate information related to their psychometric evaluation such validity and reliability. This study aimed to evaluate the psychometric property of General Health Questionnaire (GHQ) 28 which has been adapted to Indonesian language previously, to see whether it has satisfying reliability and validity, also factor analysis. The subjects of this research are 356 undergradute stduents from various university in Semarang City, Central Java. The result showed that GHQ 28 has Alpha Cronbach reliability coefficient 0,897 which considered as satisfying. Factor analysis result also showed that it has four factor solutions which confirm the origninal four factors which construct GHQ 28. In general, GHQ 28 Indonesian version has adequate psychometric properties.
\end{abstract}

Keywords: college students, General Health Questionnaire, mental health, psychometric evaluations

\begin{abstract}
Abstrak: usia remaja hingga dewasa dianggap sebagai masa yang rentan terhadap masalah kesehatan mental. Dilaporkan dalam berbagai berita maupun penelitian mahasiswa juga merupakan segmen memiliki kemungkinan tinggi mengalami masalah kesehatan mental. Salah satu hambatan utama dalam penanganan kesehatan mental di Indonesia adalah kurangnya alat skrining kesehatan mental yang adekuat. Telah terdapat beberapa alat skrining tetapi tidak disertai dengan informasi tentang evaluasi psikometris yang memadai. Penelitian ini bertujuan untuk mengevaluasi properti psikometris alat skrining General Health Questionnaire (GHQ) 28 yang sebelumnya telah diadaptasi ke dalam bahasa Indonesia untuk melihat apakah alat ini memiliki reliabilitas dan validitas yang memadai sebagai alat skrining dan memiliki faktor struktur yang sesuai dengan acuan teoretisnya. Subjek penelitian ini adalah 356 mahasiswa S1 dari berbagai universitas di Kota Semarang. Hasilnya, didapatkan koefisien reliabiliatas Alpha Cronbach 0,897 yang dianggap memuaskan. Hasil analisis faktor menunjukkan terdapat empat faktor sesuai dengan faktor asli penyusun GHQ 28. Secara umum, GHQ 28 versi terjemahan bahasa Indonesia memiliki properti psikometris yang cukup baik.
\end{abstract}

Kata kunci: evaluasi psikometris, General Health Questionnaire, kesehatan mental, mahasiswa 


\section{WACANA}

\section{Pendahuluan}

Permasalahan kesehatan mental di Indonesia terbilang memprihatinkan. Beberapa pemberitaan di media cetak ataupun elektronik menunjukkan tingginya tingkat gangguan kesehatan mental di Indonesia. Prevalensi gangguan jiwa secara keseluruhan di Indonesia adalah 1,7 per mil yang artinya ada sekitar 1-2 orang dari setiap seribu penduduk menderita gangguan jiwa (Badan Penelitian dan Pengembangan Kesehatan Kementerian Kesehatan RI, 2013).

Di antara berbagai segmen masyarakat, segmen usia remaja akhir hingga dewasa awal ternyata menunjukkan permasalahan kesehatan mental yang cukup tinggi. Hal ini ditunjukkan oleh laporan dari WHO yang menyatakan bahwa bunuh diri merupakan penyebab kematian tertinggi kedua pada usia 15-29 tahun atau sekitar 800 ribu jiwa meninggal akibat bunuh diri setiap tahunnya di seluruh dunia (World Health Organization, 2014).

Kondisi kesehatan mental mahasiswa Indonesia juga memprihatinkan. Berbagai media banyak memberitakan kasus bunuh diri yang dilakukan oleh mahasiswa, misalnya kasus terbaru yang dilakukan oleh mahasiswa di Bogor pada bulan November 2017 lalu (Sudarno, 2017). Selain itu, kasus kekerasan seperti bullying juga kerap terjadi dalam lingkungan universitas, bahkan hingga menyebabkan mahasiswa meninggal (Simbolon, 2012). Berbagai permasalahan ini menyebabkan mahasiswa rentan mengalami permasalahan kesehatan mental. Ini juga ditunjukkan oleh hasil penelitian (Maulida, 2012) menggunakan Beck Depression Inventory menunjukkan bahwa 15,6\% mahasiswa yang melakukan konsultas di Badan Konseling Mahasiswa Universitas Indonesia mengalami depresi berat dan 46,9\% mahasiswa mengalami depresi tingkat sedang. Hasil survei awal pada mahasiswa tingkat pertama Fakultas Psikologi Universitas Islam Sultan Agung tahun 2016 lalu menunjukkan bahwa permasalahan yang paling banyak dialami oleh mahasiswa tingkat awal adalah adaptasi dengan perkuliahan, terutama dalam hal metode belajar, diikuti dengan kesulitan manajemen waktu dan manajemen diri, dan kurang percaya diri. Hal ini pun berdampak pada kurang optimalnya kuliah yang diikuti dan hasil belajar yang tidak maksimal. Beberapa mahasiswa yang melakukan konsultasi psikologi juga mengeluhkan tentang kesulitannya dalam mengelola emosi sehingga mengganggu proses pembelajaran mereka di kelas. 


\section{WACANA}

Melihat permasalahan di atas, salah satu hal yang penting dalam mengembangkan layanan kesehatan mental di ranah akademis adalah perlunya alat skrining gangguan kesehatan mental yang valid dan reliabel, sehingga mampu mendeteksi secara dini gangguan kesehatan mental yang diderita oleh seseorang. Hal ini juga tampak dalam hasil survei NAMI, di mana beberapa responden menyatakan bahwa layanan kesehatan mental yang membantu adalah yang memiliki fasilitas skrining kesehatan mental, bahkan diperlukan alat skrining yang dibuat secara online (Gruttadaro \& Crudo, 2012). Lebih lanjut, skrining kesehatan mental merupakan salah satu hal yang sangat penting karena laporan yang dipublikasikan oleh WHO (2016) menunjukkan bahwa kerugian individu dan sosial akibat penurunan signifikan dari gangguan kesehatan mental sama bahkan melebihi kerugian akibat gangguan kesehatan fisik. Oleh karena itu deteksi awal gangguan kesehatan mental perlu menjadi prioritas utama agar dapat meningkatkan kesempatan seseorang dalam mendapatkan intervensi, yang dapat mengurangi risiko terjadinya gangguan yang lebih serius. Kuesioner skrining terstandar untuk mendeteksi gangguan mental banyak digunakan untuk keperluan ini. Kuesioner ini memungkinkan deteksi gangguan kesehatan mental pada banyak pasien dan dengan durasi yang singkat (Makowska, Merecz, Moscicka, \& Kolasa, 2002).

Alat skrining kesehatan mental di Indonesia masih belum banyak berkembang, sehingga diperlukan untuk melakukan adaptasi alat skrining yang telah terbukti valid dan reliabel dari luar negeri. Salah satu alat skrining yang paling banyak digunakan adalah Beck Depression Inventory (BDI), Hamilton Anxiety Scale, dan Depression Anxiety Stress Scale (DASS). Sayangnya, ketiga alat ukur tersebut hanya mampu mendeteksi gangguan kesehatan mental yang terbatas, yaitu kecemasan dan depresi. Selain itu, alat ukur tersebut juga belum dilakukan penelitian yang memadai terkait dengan evaluasi psikometrisnya. Oleh karena itu dalam penelitian ini dipilih alat skrining kesehatan mental yang disebut GHQ (General Health Questionnaire) yang dikembangkan oleh David Goldberg pada tahun 1970 di Inggris (Goldberg \& Blackwell, 1970). Dalam perkembangannya alat ini memiliki beberapa versi yaitu versi 60 butir, 30 butir, 28 butir, dan 12 butir. Berbagai versi ini telah diadaptasi ke banyak bahasa dan digunakan di berbagai negara untuk melakukan skrining gangguan kesehatan mental umum seperti gangguan somatik, kecemasan, disfungsi sosial, dan depresi. Selain skor total, 


\section{WACANA}

melalui GHQ 28 akan didapatkan skor untuk setiap sub skala di atas, sehingga cakupan skrining nya dapat lebih luas.

GHQ telah terbukti memiliki properti psikometris yang baik. Hasil penelitian validitas GHQ 12 dan 28 yang dilakukan (Goldberg et al., 1997) di 10 pusat penelitian di dunia menunjukkan bahwa kedua alat skrining tersebut valid dan memiliki area di bawah kurva ROC dengan rerata 88. Ditemukan juga bahwa tidak ada perbedaan hasil skrining antara kuesioner yang sudah diterjemahkan di bahasa lain dan antara negara maju ataupun berkembang. Lebih lanjut evaluasi psikometris GHQ 28 di Iran menunjukkan bahwa GHQ 28 memiliki koefisien reliabilitas yang baik dan berdasarkan hasil analisis faktor menunjukkan empat faktor yaitu kecemasan, depresi, disfungsi sosial, dan gejala somatik sesuai dengan faktor asli GHQ (Taghavi, 2002). Hasil penelitian (Gibbons, Arévalo, \& Monico, 2004) di El Salvador menunjukkan bahwa GHQ 28 memiliki struktur faktor yang stabil dan reliabilitas yang memuaskan, baik dengan alpha cronbach maupun pendekatan retest. Hasil penelitian di Slovenia juga menunjukkan GHQ 28 memiliki reliabilitas yang memuaskan meskipun ditemukan memiliki struktur faktor yang berbeda (Nagyova et al., 2000).

Di Indonesia, adaptasi dan evaluasi psikometris GHQ baru dilakukan pada GHQ 12 yang digunakan sebagai alat skrining cepat pasien di puskesmas, yang salah satunya dilakukan oleh (Salma \& Hidayat, 2013), yang melakukan validasi klinik GHQ 12 untuk skrining gangguan somatoform. GHQ 12 terdiri atas 12 butir pertanyaan dan memang ditujukan sebagai alat skrining cepat. Di sisi lain, untuk mendeteksi gangguan kesehatan mental dalam spektrum gangguan yang lebih luas maka dibutuhkan GHQ 28 butir yang mampu mendeteksi gangguan somatik, kecemasan, disfungsi sosial, dan depresi. Penelitian (Goldberg et al., 1997) menyarankan peneliti untuk menggunakan GHQ 28 jika menginginkan skor per subskala, yaitu depresi, kecemasan, disfungsi sosial, dan gejala somatik.

GHQ 28 telah diadaptasi oleh (Syafitri \& Choiriyah, 2017) dengan mengikuti arahan adaptasi dari MAPI Research Trust sebagai pengarah penerjemahan dan distribusi GHQ. Setelah melakukan adaptasi langkah selanjutnya adalah memeriksa validitas dan reliabilitas GHQ 28 dengan sampel masyarakat Indonesia. Evaluasi psikometris merupakan hal yang penting karena keberhasilan intervensi awal bergantung pada keakuratan dan utilitas alat skrining untuk mengidentifikasi 


\section{WACANA}

seseorang dengan risiko tinggi mengalami gangguan kesehatan mental (Stiffler \& Dever, 2015). Evaluasi psikometris yang dimaksud di sini adalah memeriksa reliabilitas dan validitas konstruk GHQ 28. Melihat pentingnya evaluasi psikometris terhadap suatu alat ukur yang baru diadaptasi dari luar negeri, penelitian ini bertujuan untuk melakukan evaluasi psikometris atas GHQ 28 versi bahasa Indonesia.

Evaluasi psikometris ini akan dilakukan dengan meminta subjek mahasiswa usia 20-25 tahun di Kota Semarang, Jawa Tengah untuk mengisi kuesioner yang telah diadaptasi tersebut lalu akan dilakukan analisis statistik untuk mengetahui properti psikometrisnya. Setelah diketahui properti psikometris nya, maka alat ukur ini akan dapat digunakan untuk melakukan skrining kesehatan mental bagi mahasiswa yang kemudian akan berguna untuk menentukan intervensi yang akan dilakukan.

Ahli pengukuran psikologis merumuskan kriteria alat ukur psikologis yang baik, yaitu reliabilitas, validitas, standar, ekonomis, dan praktis.

a. Reliabilitas

Reliabilitas berasal dari kata rely dan able, yang pada intinya berarti sejauh mana suatu hasil pengukuran dapat dipercaya. Hasil pengukuran dapat dipercaya jika dalam beberapa kali hasil pengukuran pada kelompok yang sama memberikan hasil yang relatif sama, jika perbedaannya besar maka disebut tidak reliabel. Tinggi rendahnya reliabilitas ditentukan oleh koefisien reliabilitas yang berkisar mulai dari 0,0-1,00. Untuk menentukan reliabilitas terdapat beberapa pendekatan, yang akan digunakan di sini adalah konsistensi internal menggunakan Alpha Cronbach. Reliabilitas konsistensi internal bertujuan melihat konsistensi antar butir atau antar bagian dalam tes itu sendiri. Konsistensi internal dipilih karena kemudahan pelaksanaannya, yaitu hanya membutuhkan satu kali administrasi pada sekelompok subjek (Azwar, 2011).

b. Validitas

Validitas berasal dari kata validity yang mengacu pada sejauh mana ketepatan dan kecermatan alat tes. Alat ukur memiliki validitas tinggi jika menjalankan fungsi ukurnya atau memberikan hasil ukur yang sesuati dengan maksud dilakukannya pengukuran. Selain itu, validitas juga berarti kecermatan, yaitu mampu memberikan gambaran mengenai perbedaan antar subjek yang satu 


\section{WACANA}

dengan yang lain. Terdapat beberapa jenis validitas, yaitu validitas isi yang terdiri atas validitas muka dan validitas logis, validitas konstrak, dan validitas berdasarkan kriteria yang terdiri atas validitas prediktif dan konkuren. Validitas yang digunakan di sini adalah validitas konstrak, yaitu sejauhmana tes mengungkap suatu konstrak teoretik yang akan diukur.

c. Analisis Faktor

Analisis faktor merupakan prosedur statistik yang paling banyak digunakan. Tujuan utama dari analisis faktor adalah untuk menentukan jumlah dan sifat variabel laten atau faktor yang berkontribusi dalam variasi dan kovariasi di antara serangkaian pengukuran yang diobservasi, atau sering disebut juga indikator. Secara spesifik, sebuah faktor adalah variabel yang tidak dapat diobservasi dan berkontribusi terhadap korelasi antara indikator (pengukuran yang diobservasi). Dengan kata lain, pengukuran yang diobservasi saling berkoleasi karena mereka memiliki penyebab utama (common cause) karena didasari oleh konstruk yang sama. Jadi, faktor analisis bertujuan untuk memahami secara lebih mudah kovariasi antara serangkaian indikator karena jumlah faktor yang ada kurang dari jumlah variabel yang diukur (Brown, 2006). Teknik analisis faktor yang digunakan dalam penelitian ini adalah Principal Component Analysis (PCA) yaitu teknik reduksi data untuk mengidentifikasi sejumlah komponen yang lebih sedikit, yang mendasari serangkaian variabel yang diobservasi atau butir. PCA lebih berfokus pada varians butir daripada korelasi antara butir (Harrington, 2009).

\section{B. General Health Questionnaire (GHQ)}

Goldberg mengembangkan kuesioner yang dapat diisi sendiri oleh pasien (self-administered quesionnaire), yang mampu mendeteksi gangguan psikiatris pasien. GHQ awalnya terdiri dari 60 butir yang dapat dikerjakan selama 10 menit, sehingga pasien dapat mengisinya sambil menunggu bertemu dokter. Butir GHQ 60 secara khusus didesain untuk mengidentifikasi masalah psikiatris, terdiri atas pertanyaan terkait dengan gejala fisik yang kemudian mengarah pada gejala psikiatris. Tujuan utama dari kuesioner ini adalah memberikan informasi tentang kesehatan mental pasien, serta membedakan antara pasien psikiatris dan normal (Goldberg \& Blackwell, 1970). 


\section{WACANA}

Dua aspek utama yang diukur dalam GHQ adalah 1) ketidakmampuan untuk melakukan fungsi normal dalam kehidupan sehari-hari, dan 2) munculnya gejala baru yang mengarah pada kondisi distres psikologis. Lebih lanjut, GHQ dapat digunakan untuk memperkirakan prevalensi distres psikologis dalam populasi tertentu dan dalam konteks kesehatan umum dapat mendeteksi masalah psikiatris potensial yang akan terlewatkan oleh dokter/perawat yang memeriksa. Dalam kuesioner ini, pasien diminta menilai kondisinya pada beberapa minggu belakangan dengan kondisi biasanya. Pendekatan ini membuat GHQ sensitif terhadap kondisi transisional dan mampu mendeteksi situasi pasien yang memburuk. Oleh sebab itu, alat ini tidak didesain untuk mendeteksi fenomena jangka panjang (Richard, Lussier, Gagnon, \& Lamarche, 2004).

Pada perkembangan selanjutnya, GHQ memiliki beragam versi yaitu GHQ 30 yang memiliki 30 butir, GHQ 28 yang memiliki 28 butir, dan GHQ 12 yang memiliki 12 butir. Versi GHQ yang lebih pendek dibuat berdasarkan hasil analisis faktor terhadap GHQ 60. Versi GHQ dengan 28 butir dikembangkan pada tahun 1979 oleh Goldberg dan Hillier. Versi GHQ yang lebih singkat ini merupakan hasil analisis faktor dari GHQ 60 untuk membedakan empat konsep-konsep yang saling berkait sebagai faktor, yaitu subskala A (butir 1-7) gejala somatik, subskala B (butir 8-14) kecemasan dan insomnia, subskala C (butir 15-21) disfungsi sosial, dan subskala D (butir 22-28) depresi (Goldberg \& Hillier, 1979). GHQ telah diterjemahkan ke dalam 38 bahasa, digunakan dalam lebih dari 700 artikel dalam database National Library of Medicine of the United States. Analisis faktor yang dilakukan di 15 negara mengkonfirmasi stabilitas faktor-faktor tersebut (Werneke, Goldberg, Yalcin, \& Ustün, 2000).

GHQ 28 terdiri atas 28 butir, di mana 7 butir diformulasikan dengan cara positif (contohnya "Apakah Anda merasa baik dan memiliki kesehatan yang baik?") dan 21 butir yang diformulasikan secara negatif (misalnya, "Apakah Anda merasa sakit?"). Dalam GHQ terdapat empat respon, yaitu tidak lebih dari biasanya, seperti biasa, kurang dari biasanya, dan sangat kurang dari biasanya. Metode skoring GHQ pun beragam, yaitu terdapat empat cara, yaitu model Likert (0-1-2-3), model GHQ (0-0-1-1), dan cGHQ (0-0-1-1) untuk butir positif dan 0-1-1-1 untuk butir negatif) (GL Assessment, tanpa tahun). Pada model Likert, skor yang melebihi batas nilai 4 dikategorikan mencapai "kasus psikiatris", yang artinya jika seorang 


\section{WACANA}

responden mencapai skor tersebut ia sebaiknya mendapatkan perhatian dan pemeriksaan lebih lanjut (Richard et al., 2004).

\section{Metode}

\section{a. Subjek Penelitian}

Subjek dalam penelitian ini adalah mahasiswa atau individu yang berada pada tahap perkembangan remaja akhir hingga dewasa awal yang berusia 1725. Acuan umum dalam menentukan jumlah subjek penelitian evaluasi psikometris alat ukur adalah 10-15 kali lipat jumlah butir yang ada atau minimal 300 subjek (Field, 2013).

Pengambilan data penelitian dilakukan dalam kurun waktu Juni-Juli 2018. Jumlah subjek penelitian ini adalah mahasiswa sejumlah 356 yang berasal dari berbagai universitas di Semarang, yaitu UNISSULA, UNDIP, UNNES, UIN, USM, UNIKA, POLINES, dan STIFAR. Subjek penelitian berusia 17-25 tahun dengan jumlah subjek laki-laki berjumlah 121 dan perempuan berjumlah 235 .

Tabel 1. Data Demografi Subjek

\begin{tabular}{lll}
\hline & Keterangan & Jumlah \\
\hline Jenis kelamin & Laki-laki & 121 \\
& Perempuan & 235 \\
\hline Usia & \\
& 17-20 tahun & 258 \\
& 21-25 tahun & 98 \\
\hline Tempat tinggal & & \\
& Di kos/asrama/kontrak & 239 \\
& Dengan orangtua & 117 \\
\hline Agama & & \\
& Budha & 3 \\
& Hindu & 1 \\
& Islam & 320 \\
& Katolik & 18 \\
& Kristen & 14 \\
\hline Asal Universitas & & 1 \\
& Polines & 1 \\
& Sekolah Tinggi Farmasi & 42 \\
& UIN Walisongo & 21 \\
& Universitas Diponegoro & 40 \\
& UNIKA Soegijapranata & 168 \\
& UNISSULA & 41 \\
& UNNES & 41 \\
& USM &
\end{tabular}




\section{WACANA}

Pengambilan data dilakukan dengan meminta subjek mengisi kuesioner GHQ 28 yang telah diadaptasi ke dalam bahasa Indonesia.

\section{b. Instrumen Penelitian}

Instrumen pengambilan data adalah GHQ 28 yang telah diadaptasi ke dalam bahasa Indonesia.

\section{Hasil}

\section{a. Uji Reliabilitas}

Reliabilitas yang digunakan dalam penelitian ini adalah reliabilitas internal konsistensi menggunakan Alpha Cronbach. Berdasarkan analisis yang dilakukan, koefisien Alpha Cronbach dalam penelitian ini adalah 0,897 dengan daya diskriminasi butir berkisar antara 0,109 hingga 0,661. Berikut adalah hasil deskripsi daya diskriminasi setiap butir.

Tabel 2. Daya Diskriminasi Butir

\begin{tabular}{cccc}
\hline $\begin{array}{c}\text { Nomor } \\
\text { butir }\end{array}$ & Rerata & Standar Deviasi & $\begin{array}{c}\text { Corrected Item } \\
\text { Total Correlation }\end{array}$ \\
\hline 1 & 1,35 &, 588 &, 495 \\
2 & 1,11 & 1,014 &, 408 \\
3 & 1,85 &, 879 &, 569 \\
4 & 1,29 &, 905 &, 511 \\
5 & 1,14 &, 993 &, 476 \\
6 & 1,22 &, 983 &, 580 \\
7 & 1,05 & 1,012 &, 395 \\
8 & 1,34 & 1,041 &, 481 \\
9 & 1,29 & 1,038 &, 472 \\
10 & 1,35 &, 996 &, 661 \\
11 & 1,13 &, 965 &, 455 \\
12 &, 98 &, 922 &, 589 \\
13 & 1,56 &, 982 &, 550 \\
14 &, 99 &, 941 &, 109 \\
15 &, 93 &, 783 &, 383 \\
16 & 1,46 &, 719 &, 434 \\
17 & 1,08 &, 724 &, 447 \\
18 & 1,28 &, 776 &, 278 \\
19 &, 90 &, 738 &, 378 \\
20 & 1,00 &, 777 &, 564 \\
21 & 1,36 &, 825 &, 502 \\
22 &, 58 &, 857 &, 527 \\
23 &, 33 &, 684 &, 380 \\
24 &, 31 &, 698 &, 534 \\
25 &, 17 &, 531 & \\
26 &, 53 &, 786 & \\
\hline
\end{tabular}


WACANA

\begin{tabular}{llll}
\hline 27 &, 15 &, 516 &, 419 \\
28 &, 14 &, 497 &, 405 \\
\hline
\end{tabular}

Uji reliabilitas juga dilakukan untuk setiap subskala, yaitu sebagai berikut:

Tabel 3. Hasil Uji Reliabilitas Subskala

\begin{tabular}{ccccc}
\hline & Subskala A & Subskala B & Subskala C & Subskala D \\
\hline Alpha Cronbach & 0,831 & 0,841 & 0,688 & 0,833 \\
\hline
\end{tabular}

Berikut adalah hasil analisis interkorelasi antara subskala dan skor total:

Tabel 4. Hasil Interkorelasi Subskala dengan Skor Total

\begin{tabular}{|c|c|c|c|c|c|c|}
\hline & & Subskala A & Subskala C & Subskala D & Subskala B & Total Skor \\
\hline \multirow{3}{*}{ Subskala A } & $\begin{array}{l}\text { Pearson } \\
\text { Correlation }\end{array}$ & 1 &, $392^{* *}$ & ,320** &, $495^{* *}$ &, $766^{* *}$ \\
\hline & Sig. (2-tailed) & & ,000 & ,000 & ,000 & ,000 \\
\hline & $\mathrm{N}$ & 354 & 350 & 351 & 350 & 344 \\
\hline \multirow{3}{*}{ Subskala C } & $\begin{array}{l}\text { Pearson } \\
\text { Correlation }\end{array}$ &, $392^{* *}$ & 1 &, $445^{* *}$ &, $463^{* *}$ &, $713^{* *}$ \\
\hline & Sig. (2-tailed) & ,000 & & ,000 & 000 & ,000 \\
\hline & $\mathrm{N}$ & 350 & 352 & 349 & 348 & 344 \\
\hline \multirow{3}{*}{ Subskala D } & $\begin{array}{l}\text { Pearson } \\
\text { Correlation }\end{array}$ & ,320** &, $445^{* *}$ & 1 &, $464^{* *}$ & ,693** \\
\hline & Sig. (2-tailed) & ,000 & ,000 & & ,000 & 000 \\
\hline & $\mathrm{N}$ & 351 & 349 & 353 & 350 & 344 \\
\hline \multirow{3}{*}{ Subskala B } & $\begin{array}{l}\text { Pearson } \\
\text { Correlation }\end{array}$ &, $495^{* *}$ &, $463^{* *}$ &, $464^{* *}$ & 1 &, $836^{* *}$ \\
\hline & Sig. (2-tailed) & ,000 & ,000 & ,000 & & ,000 \\
\hline & $\mathrm{N}$ & 350 & 348 & 350 & 352 & 344 \\
\hline \multirow{3}{*}{ Total Skor } & $\begin{array}{l}\text { Pearson } \\
\text { Correlation }\end{array}$ &, $766^{* *}$ &, $713^{* *}$ & ,693** & ,836** & 1 \\
\hline & Sig. (2-tailed) & ,000 & ,000 & ,000 & ,000 & \\
\hline & $\mathrm{N}$ & 344 & 344 & 344 & 344 & 344 \\
\hline
\end{tabular}

**. Correlation is significant at the 0.01 level (2-tailed).

Berdasarkan tabel di atas dapat dilihat bahwa terdapat hubungan yang sangat signifikan antar subskala. Semua subskala berkorelasi positif yang sangat signifikan dengan skor total. Subskala yang memiliki korelasi paling besar dengan skor total adalah subskala B (kecemasan dan insomnia). Lebih lanjut, subskala A, C, dan D juga memiliki korelasi paling kuat dengan subskala B. 


\section{WACANA}

\section{b. Analisis Faktor}

\section{a. Uji Asumsi}

Sebelum dilakukan faktor analisis terdapat uji asumsi yang harus dilakukan untuk menentukan apakah data yang didapat dari subjek dapat dilakukan analisis faktor. Uji yang dilakukan adalah KMO dan Bartlett's test of sphericity. Untuk dapat dilakukan analisis faktor koefisien KMO harus lebih dari 0,5 dengan $p<0,05$. Hasil uji asumsi menunjukkan koefisien KMO (Kaier-Meyer-Olkin) adalah 0,870 dengan $p=0,000, p<0,01$. Hasil analisis ini menunjukkan bahwa data yang ada dapat dilanjutkan dengan analisis faktor.

\section{b. Principal Component Analysis (PCA)}

Analisis faktor ini menggunakan ekstrasi menggunakan metode principal component dengan eigenvalue di atas 1 dan rotasi direct oblimin karena terdapat korelasi yang kuat antar subkala (faktor).

Interpretasi hasil dilakukan dalam beberapa tahap yaitu sebagai berikut:

1. Ekstraksi Faktor

Berdasarkan eigenvalue di atas 1, maka data yang ada terekstraksi menjadi 7 komponen (lihat di lampiran). Komponen pertama memiliki sumbangan komunalitas paling banyak dibandingkan 6 faktor yang lain, yaitu sebesar 27,745\%. Total komunalitas dari ketujuh komponen adalah 63,189\%. Ekstraksi faktor menjadi 4 faktor sesuai faktor asli GHQ 28 menunjukkan komunalitas sebesar 51,067\%, di mana komponen pertama memberi sumbangan terbesar yaitu $27,745 \%$.

2. Rotasi Faktor

Rotasi faktor menggunakan Varimax dengan asumsi bahwa setiap faktor dalam alat ukur ini tidak saling berhubungan. Hasilnya adalah sebagai berikut: 


\section{WACANA}

Tabel 5. Komponen yang Sudah Dirotasi

Rotated Component Matrix ${ }^{\mathrm{a}}$

\begin{tabular}{|c|c|c|c|c|c|c|c|}
\hline \multirow{2}{*}{$\begin{array}{l}\text { Nomor } \\
\text { Butir }\end{array}$} & \multicolumn{7}{|c|}{ Komponen } \\
\hline & 1 & 2 & 3 & 4 & 5 & 6 & 7 \\
\hline BUTIR 4 & ,776 & & & & & & \\
\hline BUTIR 1 & 723 & & & & & & \\
\hline BUTIR 5 & 715 & & & & & 279 & \\
\hline BUTIR 6 & ,702 & & & & & 264 & \\
\hline BUTIR 7 & 661 & & & & & & \\
\hline BUTIR 3 & ,631 & 372 & & & & & \\
\hline BUTIR 2 & ,518 & ,286 & & & & & \\
\hline BUTIR 21 & ,450 & ,288 & & ,372 & & & \\
\hline BUTIR 13 & & ,771 & & & & & \\
\hline BUTIR 12 & & ,727 & & & & & \\
\hline BUTIR 14 & & ,704 & & & & 257 & \\
\hline BUTIR 11 & & 694 & & & & & \\
\hline BUTIR 10 & 319, & ,558 & & & & ,352 & \\
\hline BUTIR 26 & & ,387 & 362 & 288 & & & \\
\hline BUTIR 28 & & & ,915 & & & & \\
\hline BUTIR 25 & & & ,888 & & & & \\
\hline BUTIR 27 & & & ,841 & & & & \\
\hline BUTIR 18 & & & & 780 & & & \\
\hline BUTIR 17 & & & & ,751 & & & \\
\hline BUTIR 19 & & & & 676 & ,413 & & \\
\hline BUTIR 20 & & & & 664 & ,323 & & \\
\hline BUTIR 23 & & & 385 & & ,718 & & \\
\hline BUTIR 22 & & 277, & & & 679 & & \\
\hline BUTIR 24 & & & 387 & & 665 & & \\
\hline BUTIR 9 & & & & & & ,822 & \\
\hline BUTIR 8 & & 304 & & & & ,811 & \\
\hline BUTIR 15 & & & & & & & ,890 \\
\hline BUTIR 16 & & & & & & &, 519 \\
\hline
\end{tabular}

GHQ 28 pada dasarnya terdiri atas empat faktor yaitu faktor A (kesehatan umum), faktor B (kecemasan dan insomnia), faktor C (disfungsi sosial), dan faktor D (depresi). Oleh karena itu, dilakukan kembali analisis faktor dengan empat faktor untuk melihat apakah data yang ada dapat membentuk empat faktor sesuai dengan konstruksi awal. Hasilnya adalah sebagai berikut: 
WACANA

Tabel 6. Komponen yang Sudah Dirotasi (4 faktor)

Rotated Component Matrix ${ }^{a}$

\begin{tabular}{|c|c|c|c|c|}
\hline \multirow{2}{*}{$\begin{array}{c}\text { Nomor } \\
\text { Butir }\end{array}$} & \multicolumn{4}{|c|}{ Komponen } \\
\hline & 1 & 2 & 3 & 4 \\
\hline BUTIR 14 & ,736 & & & \\
\hline BUTIR 12 & 723 & & & \\
\hline BUTIR 13 & ,707 & & & \\
\hline BUTIR 8 & 685 & & & \\
\hline BUTIR 10 & 662 & 321 & & \\
\hline BUTIR 11 & ,593 & & & \\
\hline BUTIR 9 & ,588 & & & \\
\hline BUTIR 16 & ,312 & 257 & & \\
\hline BUTIR 4 & & ,776 & & \\
\hline BUTIR 1 & & ,733 & & \\
\hline BUTIR 6 & 253 & ,700 & & \\
\hline BUTIR 5 & & 697 & & \\
\hline BUTIR 7 & & ,652 & & \\
\hline BUTIR 3 & 330 & 648 & & \\
\hline BUTIR 2 & &, 522 & & \\
\hline BUTIR 21 & ,323 & ,472 & & 260 \\
\hline BUTIR 15 & & 121 & & \\
\hline BUTIR 28 & & & ,885 & \\
\hline BUTIR 25 & & & ,863 & \\
\hline BUTIR 27 & & & 859 & \\
\hline BUTIR 23 & & & ,609 & ,402 \\
\hline BUTIR 24 & & &, 593 & ,338 \\
\hline BUTIR 26 & ,370 & &, 400 & 276 \\
\hline BUTIR 19 & & & & ,793 \\
\hline BUTIR 20 & & & & ,729 \\
\hline BUTIR 17 & & & & ,689 \\
\hline BUTIR 18 & & & & ,654 \\
\hline BUTIR 22 & ,314 & & ,284 & ,464 \\
\hline
\end{tabular}

Berdasarkan tabel 6 di atas, dapat dilihat bahwa faktor 1 terdiri atas butir 14, 12, 13, 8, 10, 11,9, dan 16 yang termasuk dalam subskala B (kecemasan dan insomnia), di mana butir 16 seharusnya masuk ke dalam subskala $\mathrm{C}$ (disfungsi sosial); faktor 2 terdiri atas butir $4,1,6,5,7,3,2,21$, dan 15 termasuk dalam subskala A (kesehatan umum), di mana butir 15 dan 21 seharusnya masuk ke dalam subskala C (disfungsi sosial); faktor 3 terdiri atas butir 28, 25, 27, 23, 24, dan 26 yang termasuk dalam subskala D (depresi dan bunuh diri), dan faktor 4 terdiri atas butir 19, 20, 17, 18, dan 22 termasuk dalam subskala C (disfungsi sosial) di mana butir 22 seharusnya masuk ke dalam subskala D. 


\section{WACANA}

\section{Diskusi}

Berdasarkan hasil uji reliabilitas yang telah dilakukan pada GHQ 28, dapat dilihat bahwa alat ukur ini memiliki konsistensi internal yang memuaskan yaitu dengan koefisien Alpha Cronbach 0,897. Hasil uji reliabilitas untuk setiap subskala juga menunjukkan reliabilitas yang cukup baik, yaitu berkisar antara 0,688 hingga 0,833, di mana subskala C memiliki koefisien reliabilitas yang paling rendah dibandingkan subskala lain. Lebih lanjut, dapat dilihat bahwa terdapat korelasi yang sangat signifikan antara subskala dengan skor total yang memiliki koefisien korelasi product moment berkisar antara 0,693 hingga 0,836, dengan koefisien korelasi paling tinggi adalah antara subskala B dengan skor total. Hasil penelitian (Taghavi, 2002) dengan subjek mahasiswa Iran juga menunjukkan hasil serupa dengan koefisien Alpha Cronbach 0,90 dan korelasi antara subskala dengan skor total berkisar antara 0,72 hingga 0,87. Hasil penelitian (Nagyova et al., 2000) juga menunjukkan bahwa terdapat korelasi yang tinggi antar subskala dengan skor total, di mana koefisien korelasi yang paling tinggi adalah subskala B (insomnia dan kecemasan) dengan skor total.

Daya diskriminan butir berkisar antara 0,109 sampai 0,661 di mana hampir semua butir memiliki daya diskriminasi lebih besar daripada 0,3 sehingga dianggap memuaskan, kecuali butir 15 yang memiliki daya diskriminan 0,109. Butir 15 termasuk dalam subskala C (disfungsi sosial) di mana pernyataan pada butir ini adalah "Apakah akhir-akhir ini Anda berusaha tetap sibuk dan aktif?". Pada butir ini, lebih dari 50\% subjek memilih opsi jawaban "sama seperti biasanya". Daya diskriminasi sebesar 0,109 menunjukkan bahwa butir ini tidak dapat membedakan subjek yang mengalami disfungsi sosial atau tidak. Lebih lanjut, butir 15 juga memiliki faktor loadings sebesar 0,121 yang artinya butir ini kurang representatif untuk mewakili subskala C. Rendahnya daya diskriminasi dan faktor loadings butir 15 ini juga ditemukan oleh (Nagyova et al., 2000) dengan subjek di Slovenia dan (Iwata \& Saito, 1992) dengan subjek di Jepang, dan (Cheung \& Spears, 1994) dengan subjek di Kamboja.

Analisis faktor pada penelitian ini dilakukan dengan menggunakan Principal Component Analysis (PCA) yang dilakukan dengan dua cara, yaitu cara pertama di mana faktor diesktraksi dengan syarat memiliki eigenvalue di atas 1 dan faktor diekstraksi sesuai dengan jumlah subskala yang ada, yaitu 4. 


\section{WACANA}

Berdasarkan cara pertama, dapat dilihat bahwa terdapat 7 faktor yang memiliki eigenvalue yang lebih dari 1, sehingga menunjukkan ada tujuh faktor yang terekstraksi (tabel 5) dengan komunalitas 63,189\%. Temuan di mana faktor GHQ 28 terekstrasi menjadi kurang atau lebih dari 4 faktor ditemukan oleh beberapa peneliti lain yaitu (Iwata \& Saito, 1992) yang menemukan 5-6 faktor berdasarkan eigenvalue lebih dari 1, (Molavi, 2002) menemukan menjadi 3 faktor, dan (Kiliç et al., 1997). Penelitian (Werneke et al., 2000) yang dilakukan di 15 negara dengan 11 bahasa juga menunjukkan bahwa GHQ 28 memiliki jumlah faktor yang bervariasi jika menggunakan eigenvalue lebih dari 1.

Lebih lanjut, berdasarkan loading faktor setelah diekstraksi, Faktor 1 terdiri atas butir 4, 5, 1, 7, 6, 3, 2, 21 yang cenderung pada subskala A yaitu kesehatan umum kecuali butir 21. Faktor 3 terdiri atas butir 28, 25, dan 27 yang masuk dalam subskala D (depresi dan bunuh diri), ketiga butir ini secara spesifik mengukur pikiran bunuh diri. Faktor 4 terdiri atas butir 18, 17, 19, dan 20 yang masuk dalam subskala C (disfungsi sosial), keempat butir tersebut secara spesifik mengukur kepuasan dalam mengerjakan tugas dan berperan penting dalam suatu hal. Faktor 2 terdiri atas butir $13,12,11,14,10$, dan 26 yang sebagian besar masuk ke subskala B (kecemasan) kecuali butir 26. Faktor 6 terdiri atas butir 8 dan 9 yang masuk ke subskala B (kecemasan) di mana kedua butir ini secara spesifik mengukur insomnia. Faktor 5 terdiri atas butir 23, 24, dan 22 yang masuk ke dalam subskala D (depresi dan bunuh diri), di mana ketiga butir ini mengukur tentang persepsi subjek tentang keberhargaan hidup. Faktor 7 terdiri atas butir 15 dan 16 yang masuk dalam subskala C (disfungsi sosial), kedua butir ini secara spesifik bagaimana menjalani kegiatan sehari-hari.

Berdasarkan pemaparan di atas, dapat dilihat bahwa subskala B terpecah menjadi dua yaitu faktor yaitu faktor 4 yang mengukur kecemasan secara umum dan faktor 5 yang mengukur insomnia secara spesifik. Demikian pula pada subskala C, yang terpecah menjadi faktor 3 yang mengukur kepuasan dalam melakukan tugas dan berperan penting serta faktor 7 yang secara spesifik mengukur bagaimana menjalani kegiatan sehari-hari. Subskala D juga terpecah menjadi dua faktor yaitu faktor 2 yang spesifik mengukur pikiran bunuh diri dan faktor 6 yang mengukur persepsi subjek tentang seberapa berharga hidup yang dijalani. 


\section{WACANA}

Pada cara kedua dilakukan ekstraksi butir dengan empat faktor sesuai dengan susunan asli GHQ 28 yang hasilnya butir 15 dan 21 yang seharusnya mengelompok ke subskala C justru mengelompok ke subskala A, butir 22 yang seharusnya mengelompok ke subskala D justru mengelompok ke subskala B, dan butir 16 yang seharusnya mengelompok ke subskala C justru mengelompok ke subskala D. Terdapat total empat butir yaitu 15, 16, 21, dan 22 yang tidak mengelompok sesuai dengan subskalanya. Butir yang faktor loadings nya tidak masuk ke faktor aslinya juga ditemukan dalam berbagai penelitian misalnya (Kiliç et al., 1997) dengan sampel di Turki.

Berdasarkan berbagai hasil penelitian analisis faktor GHQ 28, disimpulkan bahwa faktor struktur GHQ 28 kemungkinan besar sudah berubah sejak awal pembentukannya. Hal ini karena banyaknya hasil penelitian analisis faktor GHQ 28 (termasuk penelitian ini) yang jika menggunakan eigenvalue lebih dari 1 dihasilkan lebih atau kurang dari empat faktor. Hal ini disebutkan oleh (Werneke et al., 2000) di mana perubahan struktur ini dimungkinkan oleh proses penerjemahan alat ukur, perubahan sosial, dan perbedaan karakter sampel. Meskipun demikian, hasil penelitian ini secara umum serupa dengan hasil-hasil penelitian sebelumnya di mana GHQ 28 memiliki koefisien reliabilitas Alpha Cronbach yang termasuk dalam kategori baik, daya diskriminasi butir yang baik kecuali pada butir 15, dan ditemukan adanya empat faktor dengan empat butir yang mengalami cross loadings.

\section{Kesimpulan}

Berdasarkan hasil penelitian ini, dapat dilihat bahwa GHQ 28 memiliki properti psikometris yang cukup baik, yaitu koefisien reliabilitas Alpha Cronbach sebesar 0,897 dan daya diskrimnasi butir berkisar antara 0,109 hingga 0,661. Berdasarkan analisis faktor dengan teknik rotasi Varimax dan pedoman ekstraksi eigenvalue lebih dari 1 ditemukan bahwa GHQ 28 menghasilkan tujuh faktor dan jika data diekstraksi menjadi empat faktor ditemukan terdapat empat butir yaitu butir 15, 16, 21, dan 22 yang tidak mengelompok sesuai dengan faktor aslinya. Pada akhirnya penelitian lain di berbagai negara menunjukkan bahwa adanya kemungkinan faktor penyusun GHQ 28 sudah tidak lagi sama dengan faktor penyusun aslinya. Hal ini dimungkinkan karena adanya proses adaptasi alat ukur dan lokasi tempat pengambilan data yang berbeda-beda. 


\section{WACANA}

\section{Implikasi}

Saran untuk penelitian selanjutnya adalah melakukan validasi alat ukur ini dengan alat lain yang merupakan standar baku diagnosis depresi, kecemasan, gangguan kesehatan umum, dan disfungsi sosial.

Acknowledgment: dana penelitian ini berasal dari hibah penelitian internal Lembaga Penelitian dan Pengabdian Masyarakat Universitas Islam Sultan Agung. Dalam proses pengambilan data peneliti dibantu oleh Muhammad Rifqy, Endang Muslichatun Hasanah, Raafi Happy W.

\section{Referensi}

Azwar, S. (2011). Reliabilitas dan Validitas Edisi Ketiga. Yogyakarta: Pustaka Pelajar.

Badan Penelitian dan Pengembangan Kesehatan Kementerian Kesehatan RI. (2013). RISET KESEHATAN DASAR. Jakarta.

Brown, T. A. (2006). Confirmatory Factor Analysis for Applied Research. New York: The Guilford Press.

Cheung, P., \& Spears, G. (1994). Reliability and validity of the Cambodian version of the 28-item General Health Questionnaire. Social Psychiatry and Psychiatric Epidemiology, 29, 95-99.

Field, A. (2013). Discovering Statistics Using SPSS. Sage (Second Edi, Vol. 81). London: Sage Publication. http://doi.org/10.1111/insr.12011_21

Gibbons, P., Arévalo, F. De, \& Monico, M. (2004). Assessment of the factor structure and reliability of the 28 item version of the General Health Questionnaire ( GHQ-28 ) in El Salvador. International Journal of Clinical and Health Psychology, $4(2), 389-398$.

Goldberg, D., Gater, R., Sartorius, N., Utsun, T. B., Piccinelli, M., Gureje, O., \& Rutter, C. (1997). The Validity of two Versions of the GHQ in the WHO Study of Mental Illness in General Health. Psychological Medicine1, 27, 191-197. http://doi.org/10.1017/S0033291796004242

Goldberg, D. P., \& Blackwell, B. (1970). Psychiatric illness in general practice. A detailed study using a new method of case identification. British medical journal, 1(5707), 439-43. http://doi.org/10.1136/bmj.1.6013.793

Gruttadaro, D., \& Crudo, D. (2012). College students speak: A survey report on mental health. National Alliance on Mental Illness. Arlington.

Harrington, D. (2009). Confirmatory Factor Analysis: Pocket Guide to Social Work Research Method. Oxford: Oxford University Press. 


\section{WACANA}

Iwata, N., \& Saito, K. (1992). The Factor Structure of the 28-Item General Health Questionnaire when Used in Japanese Early Adolescents and Adult Employees: Age- and Cross-Cultural Comparisons. European Archives of Psychiatry and Clinical Neuroscience, (242), 172-178.

Kiliç, C., Rezaki, M., Rezaki, B., Kaplan, I., Özgen, G., Sağduyu, A., \& Ozẗrk, M. O. (1997). General Health Questionnaire (GHQ12 and GHQ28): Psychometric properties and factor structure of the scales in a Turkish primary care sample. Social Psychiatry and Psychiatric Epidemiology, 32(6), 327-331. http://doi.org/10.1007/BF00805437

Makowska, Z., Merecz, D., Moscicka, A., \& Kolasa, W. (2002). THE VALIDITY OF GENERAL HEALTH QUESTION- NAIRES , GHQ-12 AND GHQ-28 , IN MENTAL HEALTH STUDIES OF WORKING PEOPLE. International Journal of Occupational Medicine and Environmental Health, 15(4), 353-362.

Maulida, A. (2012). Gambaran Tingkat Depresi pada Mahasiswa Program Sarjana yang Melakukan Konseling di Badan Konseling Mahasiswa Universitas Indonesia. Universitas Indonesia. Universitas Indonesia.

Molavi, H. (2002). Validation, Factor Structure, and Reliability of the Farsi Version of General Health Questionnaire-28 on Irani Students. Pakistan Journal of Psychological Research, 17(3-4), 87-98.

Nagyova, I., Krol, B., Szilasiova, A., Stewart, R. E., Dijk, J. P. Van, \& Heuvel, W. J. a Van Den. (2000). General Health Questionnaire-28: psychometric evaluation of the Slovak version. Studia Psychologica, 42(4), 351-361. http://doi.org/10.4172/2329-6879.1000178

Richard, C., Lussier, M. T., Gagnon, R., \& Lamarche, L. (2004). GHQ-28 and cGHQ-28: Implications of two scoring methods for the GHQ in a primary care setting. Social Psychiatry and Psychiatric Epidemiology, 39(3), 235-243. http://doi.org/10.1007/s00127-004-0710-3

Salma, \& Hidayat, R. (2013). Validasi Klinik General Health Questionnaire-12 Sebagai Instrumen Skrining Gangguan Somatoform di Puskesmas. Universitas Gadjah Mada.

Simbolon, M. (2012). Perilaku Bullying pada Mahasiswa Berasrama. Jurnal Psikologi, 39(2), 233-243.

Stiffler, M. C., \& Dever, B. V. (2015). Mental Health Screening at School: Instrumentation, Implementation, and Critical Issues. (R. W. Kamphaus, Ed.). New York: Springer International Publishing. http://doi.org/10.1007/978-3319-19171-3

Sudarno, A. (2017). Pesan Haru Mahasiswa di Bogor Sebelum Tewas Gantung Diri News Liputan6. Diambil 6 Februari 2018, dari http://news.liputan6.com/read/3155762/pesan-haru-mahasiswa-di-bogorsebelum-tewas-gantung-diri 


\section{WACANA}

Syafitri, D. U., \& Choiriyah, D. W. (2017). Adaptasi Bahasa General Health Questionnaire (GHQ 28) sebagai Instrumen Skrining Kesehatan Mental Mahasiswa. Semarang.

Taghavi, M. R. (2002). Validity and reliability of the general health questionnaire (ghq-28) in college students of shiraz university. Journal of psychology, 5(4), 381-398.

Werneke, U., Goldberg, D. P., Yalcin, I., \& Ustün, B. T. (2000). The stability of the factor structure of the General Health Questionnaire. Psychological medicine, 30(4), 823-9. http://doi.org/10.1017/S0033291799002287

World Health Organization. (2014). Preventing suicide. WHO Press (Vol. 143). Geneva: WHO Press. http://doi.org/ISBN: 9789241564779 